\author{
K.N. Seitkamal ${ }^{1,2}$, N.K. Zhappar ${ }^{1}$, \\ V.M. Shaikhutdinov ${ }^{1}$, A.K. Shibayeva ${ }^{1}$, U.Z. Sagyndykov ${ }^{2}$ \\ ${ }^{I}$ Scientific-analytical center «Biomedpreparat», Stepnogorsk, Kazakhstan; \\ ${ }^{2}$ Eurasian National University, Nur-Sultan, Kazakhstan \\ (*E-mail: mengoibyti@gmail.com)
}

\title{
A comparative study on psychrophilic and mesophilic biooxidation of ferrous iron by pure cultures of Acidithiobacillus ferrooxidans and Acidithiobacillus ferrivorans
}

\begin{abstract}
Biological oxidation of ferrous sulfate by Acidithiobacillus ferrooxidans and Acidithiobacillus ferrivoransis an important process in the bioleaching of minerals and the treatment of acid mine drainage. The rate at which biooxidation reactions take place is directly related to the microorganisms'growth temperature. Decreasing the temperature of reaction causes both a decrease on the chemical reactions rates and a decrease on bacterial growth. In this study, the effects of $\mathrm{pH}$ and temperatures on oxidation of ferrous sulfate by a native At. ferrooxidans and At. ferrivorans strains were investigated. The biooxidation tests conducted in shake flasks at $28^{\circ} \mathrm{C}$ and $8{ }^{\circ} \mathrm{C}$ and at initial $\mathrm{pH} 1.6$ for 5 days. During the experiment, the mesophilic iron oxidizers were capable of growing on ferrous iron at concentrations of $4.5 \mathrm{~g} / \mathrm{L}$ at low and optimum temperature. However, the rate of mesophilic biooxidation of ferrous iron was higher than that observed in the psychrophilic biooxidation. In conclusion, during the experiment the At. ferrivorans strain 535 showed high activity in oxidizing at low temperature than other strains. It means even at very low temperatures, microorganisms play an important role in the oxidation and leaching of sulphide ores.
\end{abstract}

Keywords: bioleaching, Acidithiobacillus ferrooxidans, Acidithiobacillus ferrivorans, biooxidation, ferrous iron, psychrophilicbiooxidation, mesophilicbiooxidation, low temperature, iron oxidation, sulphideores.

\section{Introduction}

Bioleaching is extraction of valuable metals from their ores using microorganisms. It as environmentally friendly technology offers an alternative to traditional pyrometallurgical methods [1]. There are two mechanisms for bioleaching of sulphideminerals: the direct and the indirect. In the direct mechanism, microorganisms situated at the mineral surface and dissolve metal ions. In the indirect mechanism, metal sulfides are chemically attacked by ferric iron, which is oxidized to sulfuric acid [2,3]. Biooxidation of ferrous iron wereproven to be anessential step in bioleaching $[4,5]$. Due to their importance in the bioleaching of sulfide minerals, the oxidative activity of chemolithotrophic microorganisms such as archaea and bacteria in a mesophilic and cold environments as well as moderately high and extremely high temperatures has been widely studied. Microorganisms have been frequently isolated from sulphide minerals in dumps, heaps and from flotation tailings are Acidithiobacillus ferrooxidans, Acidithiobacillus thiooxidans, Acidithiobacillus ferrivorans, etc. [6-9]. Flotation tailings are one of the largest mining wastes from sulphide minerals concentrated by pyrometallurgical process generated during the flotation process. In Kazakhstan over 22 billion tons of waste, of which more than 16 billion tons of mining and processing waste, about 6 billion tons of hazardous waste has been accumulated [10-14]. Thus, in order to reduce the health risk arising from the heavy metals such as arsenic, lead, and chromium it is necessary to develop strategies that could reduce toxicity. In this aspect, biogeotechnology, which is based on the natural ability of chemolithotrophic bacteria (At. ferrivorans, At.ferrooxidans, At.thiooxidans, etc.) is of great help to utilize either ex-situ or in-situ bioremediation of heavy metal polluted sites. The kinetics of mesophilic biooxidation of ferrous iron has been studied in our previous work [9].

To date, many studies on the biooxidation of ferrous iron using At. ferrooxidans are reported [13-15]. However, few experiments on biooxidation of iron by At. ferrivorans was conducted and several documents about biooxidation of ferrous iron by At. ferrooxidans at low temperatures were reported [4, 16-18]. The aim of this work is to assess the At. ferrivorans strains biooxidation of ferrous iron and to compare the rate of this reaction with At. ferrooxidansstrains biooxidation of ferrous iron at different temperatures. 


\section{Materials and Methods}

\section{Microorganism and medium}

The mesophilic iron oxidizers used in this study were 535 strain of At. ferrivoransand strains FT-2, FT-3 and 377 of At. ferrooxidanswhich was been previously isolated from gold deposits by our laboratory. The microorganisms were grown on a modified medium $9 \mathrm{~K}-\mathrm{Fe}$ containing (in grams per liter): $\mathrm{KH}_{2} \mathrm{PO}_{4}$ (3.0), $\mathrm{MgSO}_{4} \cdot 7 \mathrm{H}_{2} \mathrm{O}(0.5),\left(\mathrm{NH}_{4}\right)_{2} \mathrm{SO}_{4}(3.0), \mathrm{KCl}(0.1), \mathrm{Ca}\left(\mathrm{NO}_{3}\right)_{2}(0.01)$. The medium also supplemented with filter-sterilized $\mathrm{FeSO}_{4} \cdot 7 \mathrm{H}_{2} \mathrm{O}$ (22.1). The cultures of At. ferrivorans and At. ferrooxidans were incubated in $750 \mathrm{~mL}$ Erlenmeyer flasks each containing $200 \mathrm{~mL}$ of the medium and $10 \%(\mathrm{v} / \mathrm{v})$ inoculumon a shakerincubator at $200 \mathrm{rpm}$ at a temperature of $28{ }^{\circ} \mathrm{C}$. The initial $\mathrm{pH}$ of the cultures was adjusted to 1.6 at room temperature using $10 \mathrm{~N} \mathrm{H}_{2} \mathrm{SO}_{4}$.

Biooxidation experiments at low temperature

In order to study on ferrous iron biooxidationof different strains at low and optimal temperatures the experiments were realized in $250 \mathrm{~mL}$ sterile shake flasks containing $90 \mathrm{~mL}$ of the modified medium $9 \mathrm{~K}-\mathrm{Fe}$ (concentrations of ferrous iron was $4.5 \mathrm{~kg} \cdot \mathrm{m}^{-3}$ ) and $10 \%(\mathrm{v} / \mathrm{v})$ inoculum. The flasks were incubated on a rotary shaker at $160 \mathrm{rpm}$ and temperatures of $8{ }^{\circ} \mathrm{C}$ and $28^{\circ} \mathrm{C}$. Samples were taken every day and analyzed for ferrous, total iron concentrations and $\mathrm{pH}$. All the experiments were carried out under sterile conditions.

Analytical analysis

The $\mathrm{pH}$ of the test solutions was determined using a professional multichannel $\mathrm{pH}$ meter Mettler Toledo SevenMulti-A. The concentration of total iron and $\mathrm{Fe}^{2+}$ ions in the liquid phase was determined spectrophotometrically using a spectrometer (BioMate 3S UV-Visible, Thermo Scientific, USA)

\section{Results and Discussion}

Results of mesophilic biooxidation of ferrous iron at initial concentration of $4.5 \mathrm{~g} / \mathrm{L}$ are presented in Figure 1. The biooxidation rate of ferrous iron $\left(\mathrm{Fe}^{2+}\right)$ to ferric iron $\left(\mathrm{Fe}^{3+}\right)$ was remarkably increasing in the flasks with microorganisms for 3 days, meantime in un-inoculated flask oxidation of $\mathrm{Fe}^{2+}$ was not happen: due to slow chemical oxidation. Despite added ferrous iron concentration was $4.5 \mathrm{~g} / \mathrm{L}$, at the end of the experiment the oxidized ferrous iron concentration was $4.8 \mathrm{~g} / \mathrm{L}$. The reason for increasing of the total iron is the added inoculum culture with $9 \mathrm{~g} / \mathrm{L}$ of iron. The strains 377 and 535 showed the highest activity. Variations of $\mathrm{pH}$ over time during the biooxidation process with different bacterial strains at $28{ }^{\circ} \mathrm{C}$ are shown in Figure 2. The $\mathrm{pH}$ of the flasks inoculated with At. ferrooxidans FT-2 decreased significantly within the first 3 days of the experiment from $\mathrm{pH} 1.64$ to 1.58 . The $\mathrm{pH}$ propagation of 535 and FT-3cultures was quite similar. In the flasks with $377, \mathrm{pH}$ was increased from 1.6 to 1.63 . Meanwhile the $\mathrm{pH}$ did not drop greatly in the control flasks, which were conducted without bacterial inoculation.

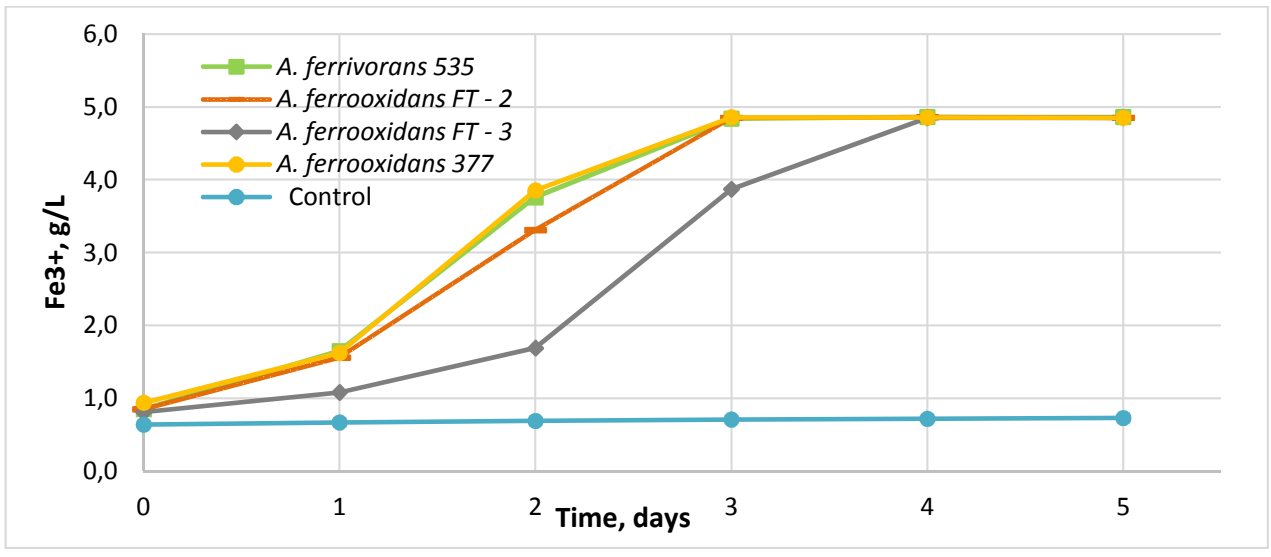

Figure 1. Mesophilic biooxidation of ferrous iron at $28^{\circ} \mathrm{C}$ 


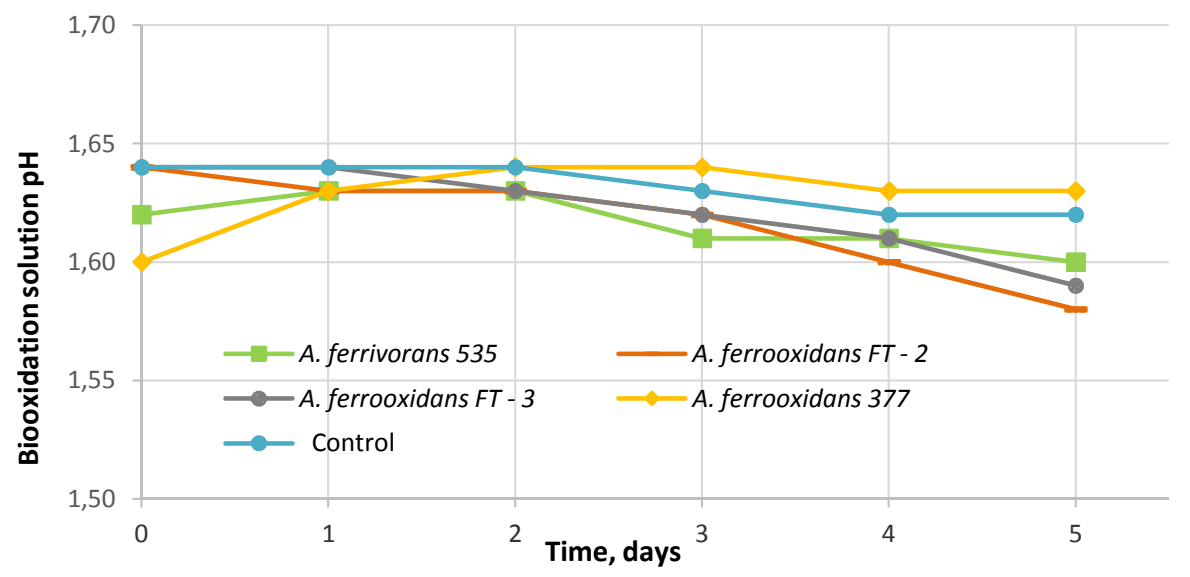

Figure 2. Variation of $\mathrm{pH}$ over time during biooxidation process of the ferrous iron at $28{ }^{\circ} \mathrm{C}$

In Figure 3 the observed oxidation of $\mathrm{Fe}^{2+}$ to $\mathrm{Fe}^{3+}$ clearly demonstrates the presence in four type of strains growing at $8{ }^{\circ} \mathrm{C}$ and able to oxidize $\mathrm{Fe}^{2+}$ iron at initially $\mathrm{pH} 1.6$. In the flasks with microorganisms, the ferrous iron initially added was rapidly oxidized to $\mathrm{Fe}^{3+}$ after only 5 days. The A. ferrooxidans FT-2 strain showed the highest activity which was demonstrated by an increase of $\mathrm{Fe}^{3+}$ in solution. A small amount of $\mathrm{Fe}^{2+}$ (approximately $1.0 \mathrm{mg} / \mathrm{L}$ ) was maintained in the media with the strain of $A$. ferrooxidans $\mathrm{FT}-3$ till the end of the experiment. In the sterile flasks, some chemical oxidation was also obtained after 5 days. Figure 4 illustrates the results of the biooxidation of ferrous iron at initial $\mathrm{pH}$ 1.6. The trend of $\mathrm{pH}$ variations during biooxidation of $\mathrm{Fe}^{2+}$ to $\mathrm{Fe}^{3+}$ showed that the $\mathrm{pH}$ of the flasks with microorganismswas not decreased within the first 5 days of the experiment.

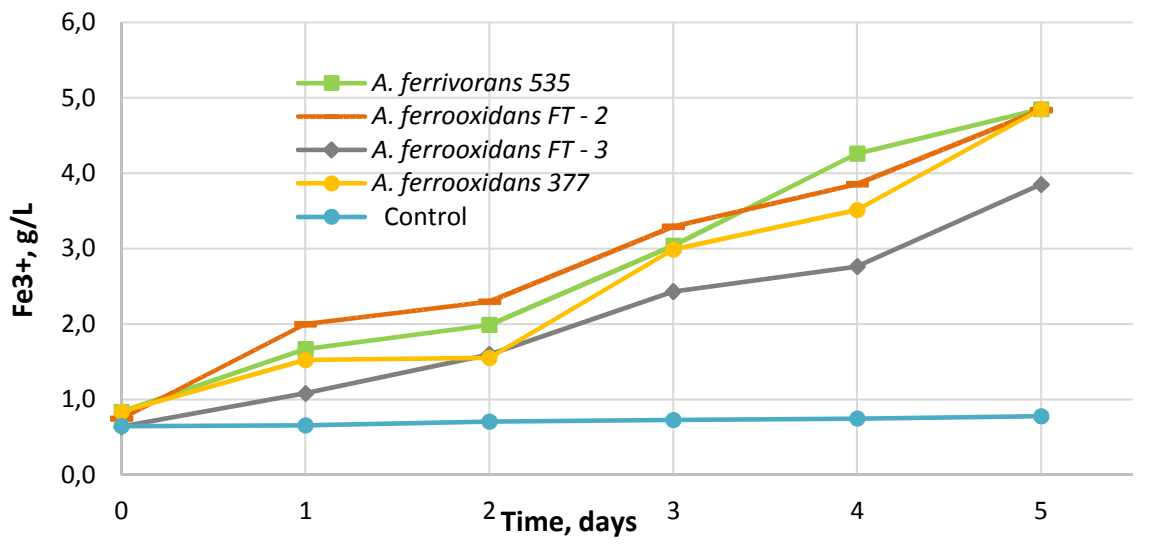

Figure 3. Psychrophilic biooxidation of ferrous iron at $8{ }^{\circ} \mathrm{C}$

According to this study, these isolated strains of At. ferrooxidans and At. ferrivorans would be psychro tolerant despite the fact that optimum growth temperature is $20-40{ }^{\circ} \mathrm{C}$, they also can grow at $8{ }^{\circ} \mathrm{C}$. However, they cannot be considered psychrophilic, as they showed high growth at $28^{\circ} \mathrm{C}$. Temperature is a significant factor in leaching processes, especially in oxidation processes. Lowering the temperature leads to a significant reduction in the rate of oxidation. The rate of chemical oxidation of sulfide minerals with oxygen at environing temperature is very slow. And a significant oxidation might be observed only in the presence of iron-sulfur oxidizing bacteria. Abandoned mines exposed to atmospheric influences at ambient temperature leads to the formation of acid drainage, which cause environmental pollution. However, the results of this study show that even at a very low temperature $\left(8^{\circ} \mathrm{C}\right)$, bacterial growth occurs and biological catalysis increases the rate of oxidation. 


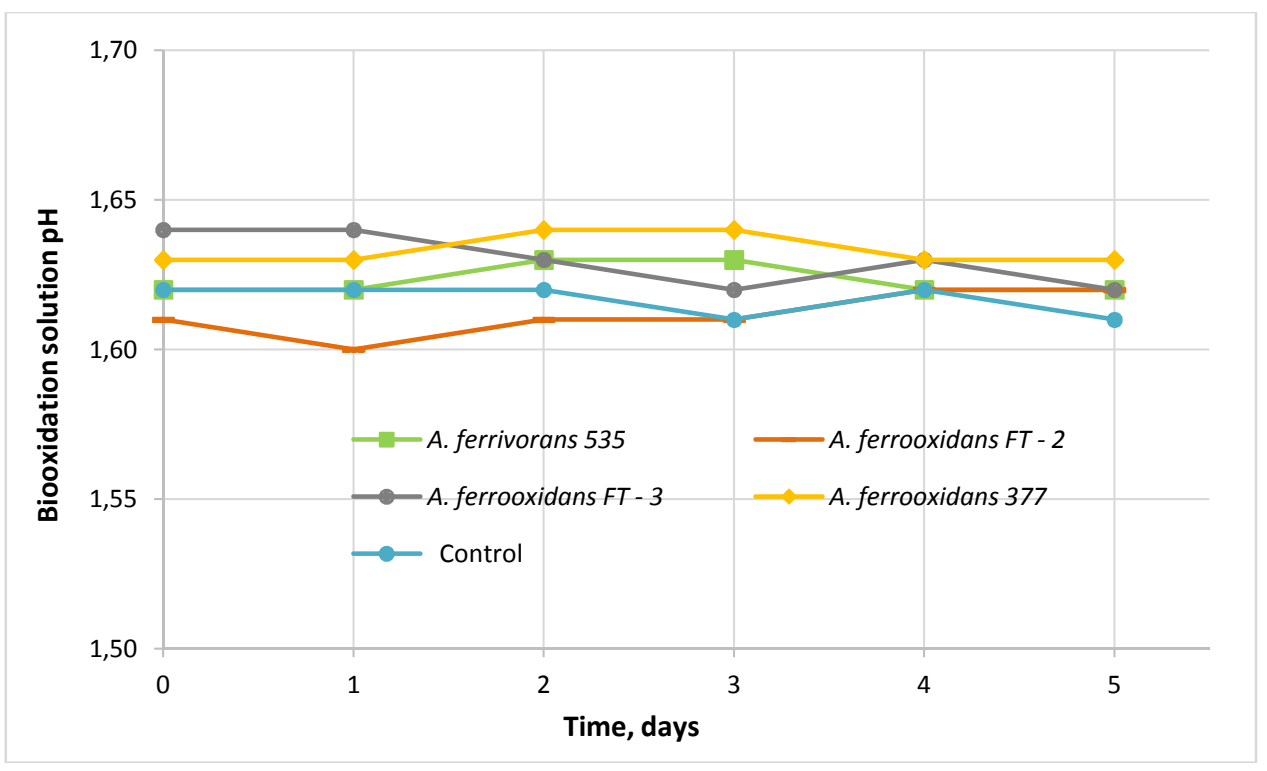

Figure 4. Variation of $\mathrm{pH}$ over time during biooxidation process of the ferrous iron at $8{ }^{\circ} \mathrm{C}$

These results of the study are important not only from an environmental point of view but also the possible development biological leaching of low-grade oredeposits located in low-temperature areas.

\section{Conclusion}

Results of the present study show that the mesophilic microorganisms At. ferrivorans and At.ferrooxidans are able to grow on ferrous iron at concentrations below $5 \mathrm{~g} / \mathrm{L}$ and at $\mathrm{pH}$ 1.6. As experimental parameters, initial $\mathrm{pH} 1.6$, temperature $\left(8\right.$ and $\left.28^{\circ} \mathrm{C}\right)$, and ferrous iron concentration $4.5 \mathrm{~g} / \mathrm{L}$ were used, and their effects on ferrous iron oxidation behaviors were studied. In terms of the ferrous iron oxidation behavior according to the reaction temperature, the highest oxidation rate was observed at $28{ }^{\circ} \mathrm{C}$, and a lower ferrous iron oxidation efficiency was observed at $8{ }^{\circ} \mathrm{C}$. After 3 days of incubation at $28^{\circ} \mathrm{C}$, At. ferrooxidans strain 377 was found to be the most effective bacteria compared to other strains for oxidation of ferrous iron; meanwhile, at $8^{\circ} \mathrm{C}$, At. ferrivorans strain 535 showed the higher efficiency on biooxidation of ferrous iron when compared with At. ferrooxidans.

From the results of the study, it was noted that the selection of bacterial strains to be used for the biooxidation process should depend on temperature of environment. There remains a need for furtherresearch to verify various reactions engaged inpsychrophilic bioleaching of sulphide minerals and to explain the mechanism which dominates this process.

This work was supported by the Science Committee of the Ministry of Education and Science of the Republic of Kazakhstan in the framework of program funding for research (AP05136008).

\section{References}

1 Ngoma E. Bioleaching of arsenopyrite from Janggun mine tailings (South Korea) using an adapted mixed mesophilic culture / E. Ngoma, D. Borja D., M. Smart, K. Shaik, H. Kim, J. Petersen, S.T.L. Harrison // Hydrometallurgy. — 2018. — Vol. 181. — P. 21-28. - URL: https://doi.org/10.1016/j.hydromet.2018.08.010.

2 Long Z.E. Biooxidation of ferrous iron by immobilized Acidithiobacillus ferrooxidans in poly(vinyl alcohol) cryogel carriers / Z.E. Long, Y. Huang, Z. Cai, W. Cong, F. Ouyang // Biotechnology Letters. - 2003. — Vol. 25, Iss. 3. — P. 245-249. — URL: https://doi.org/10.1023/A:1022389510891.

3 Nemati M. Comparative study on thermophilic and mesophilic biooxidation of ferrous iron / M. Nemati, S.T.L. Harrison // Minerals Engineering. - 2000. - Vol. 13, Iss. 1. - P. 19-24. — URL: https://doi.org/10.1016/S0892-6875(99)00146-6.

4 Escobar B. Biooxidation of ferrous iron and sulphide at low temperatures: Implications on acid mine drainage and bioleaching of sulphide minerals / B. Escobar, S. Buccicardi, G. Morales, J. Wiertz // Hydrometallurgy. — 2010. — Vol. 104, Iss. 3-4. — P. 454-458. https://doi.org/10.1016/j.hydromet.2010.03.027.

5 Meruane G. Bacterial oxidation of ferrous iron by Acidithiobacillus / G. Meruane // Hydrometallurgy. — 2003. — Vol. 71. — P. 149-158. — URL: https://doi.org/10.1016/S0304-386X(03)00151-8. 
6 Franzmann P.D. Effects of temperature on the rates of iron and sulfur oxidation by selected bioleaching Bacteria and Archaea: Application of the Ratkowsky equation / P.D. Franzmann, C.M. Haddad, R.B. Hawkes, W.J. Robertson, J.J. Plumb // Minerals Engineering. - 2005. — Vol. 18, Iss. 13-14. — P. 1304-1314. — URL: https://doi.org/10.1016/j.mineng.2005.04.006.

7 Nguyen V.K. Bioleaching of arsenic and heavy metals from mine tailings by pure and mixed cultures of Acidithiobacillus spp. / V.K. Nguyen, M.H. Lee, H.J. Park, J.U. Lee // Journal of Industrial and Engineering Chemistry. — 2015. — Vol. 21. P. 451-458. — URL: https://doi.org/10.1016/j.jiec.2014.03.004.

8 Rawlings D.E. Characteristics and adaptability of iron- and sulfur-oxidizing microorganisms used for the recovery of metals from minerals and their concentrates / D.E. Rawlings // Microbial Cell Factories. - 2005. - No. 4. - P. 1-15. - URL: https://doi.org/10.1186/1475-2859-4-13.

9 Zhappar N.K. Bacterial and chemical leaching of copper-containing ores with the possibility of subsequent recovery of trace silver / N.K. Zhappar, V.M. Shaikhutdinov, Y.N. Kanafin, O.A. Ten, D.S. Balpanov, I.V. Korolkov, S.R. Collinson, R.S. Erkasov, A.A. Bakibaev // Chemical Papers. — 2019. — Vol. 73, Iss. 6. — P. 1357-1367. — URL: https://doi.org/10.1007/s11696-01900688-y.

10 Lim K.T. Physical, chemical, and biological methods for the removal of arsenic compounds / K.T. Lim, M.Y. Shukor, H. Wasoh // BioMed Research International. — 2014. — URL: https://doi.org/10.1155/2014/503784.

11 Tsai S.L. Arsenic metabolism by microbes in nature and the impact on arsenic remediation / S.L. Tsai, S. Singh, W. Chen // Current Opinion in Biotechnology. — 2009. - Vol. 20, Iss. 6. - P. 659-667. https://doi.org/10.1016/j.copbio.2009.09.013.

12 Novikov V. Foreword Country prooles: Management of waste and chemicals Waste in Central Asia Chemicals in Central Asia Synergies and hotspots Sound management practices / V. Novikov // Success stories. Recommendations. — 2013.

13 Ko M.S. The role of Acidithiobacillus ferrooxidans and Acidithiobacillus thiooxidans in arsenic bioleaching from soil / M.S. Ko, H.S. Park, K.W. Kim, J.U. Lee // Environmental Geochemistry and Health. — 2013. - Vol. 35, Iss. 6. - P. 727-733. URL: https://doi.org/10.1007/s10653-013-9530-2.

14 Quatrini R. Acidithiobacillus ferrooxidans / R. Quatrini, D.B. Johnson // Trends in Microbiology. — 2019. — Vol. 27 , Iss. 3. — P. 282-283. — URL: https://doi.org/10.1016/j.tim.2018.11.009.

15 Rawlings D.E. Thiobacillus caldus and Leptospirillum ferrooxidans are widely distributed in continuous flow biooxidation tanks used to treat a variety of metal containing ores and concentrates / D.E. Rawlings, N.J. Coram, M.N. Gardner, S.M. Deane // Process Metallurgy. - 1999. — Vol. 9. — P. 777-786. — URL: https://doi.org/10.1016/S1572-4409(99)80080-7.

16 Elberling B. Bacterial and chemical oxidation of pyritic mine tailings at law temperatures / B. Elberling, A. Schippers, W. Sand // Journal of Contaminant Hydrology. - 2000. - Vol. 41, Iss. 3-4. - P. 225-238. — URL: https://doi.org/10.1016/S01697722(99)00085-6.

17 Hallberg K.B. Acidithiovbacillus ferrivorans, sp.nov.; facultatively anaerobic, psychrotolerant iron-, and sulfur-oxidizing acidophiles isolated from metal mine-impacted environments / K.B. Hallberg, E. Gonzalez-Toril, D.B. Johnson // Extremophiles. 2010. — Vol. 14, Iss. 1. - P. 9-19. — URL: https://doi.org/10.1007/s00792-009-0282-y.

18 Peng T. Dissolution and passivation of chalcopyrite during bioleaching by acidithiobacillus ferivorans at low temperature / T. Peng, L. Chen, J. Wang, J. Miao, L. Shen, R. Yu, G. Gu. G. Qiu, W. Zeng / Minerals. — 2019. — Vol. 9, Iss. 6. — P. 4-13. https://doi.org/10.3390/min9060332.

\title{
Қ.Н. Сейткамал, Н.Қ. Жаппар, В.М. Шайхутдинов, А.К. Шибаева, Ө.З. Сағындықов \\ Таза дақылдардағы екі валентті темірдің психрофильді және мезофильді биототықтыруын салыстырмалы зерттеу
}

\begin{abstract}
Acidithiobacillus ferrooxidans және Acidithiobacillus ferrivorans микроағзаларындағы темір сульфатын биологиялық тотықтыру минералдардың биологиялық сілтіленуіне және шахта дренаждарының қышқылын өңдеуде маңызды процесс болып табылады. Биологиялық тотығу реакцияларының жүру жылдамдығы сол ортадағы микроорганизмдердің өсу температурасына тікелей байланысты болып келеді. Реакция температурасының төмендеуі химиялық реакциялар жылдамдығының төмендеуіне, сонымен қоса бактериялардың көбеюіне де әсер етеді. Жұмыста At. ferrooxidans және At. Ferrivorans темір сульфатын тотықтыруында $\mathrm{pH}$ пен температураның әсерлері зерттелді. Биологиялық тотықтыру эксперименті бастапқы $\mathrm{pH} 1,6$ деңгейінде және температурасы $28^{\circ} \mathrm{C}$ мен $8{ }^{\circ} \mathrm{C}$ болатын, 5 тәулік ішінде шайқауға арналған арнайы шыны сауыттарында жүргізілді. Нәтижесінде, мезофильді темір тотықтырғыштары екі валентті темірдің 4,5 г/л концентрациясында төмен температура жағдайында өсе алады. Алайда, темірдің мезофильді биототығу жылдамдығы психрофильді биототығуға қарағанда жоғары болды. Қорытындылай келе, эксперимент кезінде төмен температурада тотықтыруда At. ferrivorans 535 штамы басқа штамдарға қарағанда жоғары белсенділік көрсетті. Бұл дегеніміз, өте төмен температура жағдайларындада микроағзалар сульфидті кендерді тотықтыру және сілтілендіруде маңызды рөл атқарады.
\end{abstract}

Кілт сөздер: биологиялық сілтілеу, Acidithiobacillus ferrooxidans, Acidithiobacillus ferrivorans, биототығу, екі валентті темір, психрофильді биототығу, мезофильді биототығу, төмен температура, темірдің тотығуы, сульфидті кендер. 
К.Н. Сейткамал, Н.К. Жаппар, В.М. Шайхутдинов, А.К. Шибаева, У.З. Сагындыков

\title{
Сравнительное исследование психрофильного и мезофильного биоокисления двухвалентного железа чистыми культурами
}

\begin{abstract}
Биологическое окисление сульфата железа микроорганизмами Acidithiobacillus ferrooxidans и Acidithiobacillus ferrivorans является важным процессом биологического выщелачивания минералов и обработки кислотных шахтных дренажей. Скорость реакции биоокисления напрямую связана с температурой роста микроорганизмов, которые находятся там. Снижение температуры реакции приводит как к снижению скорости химических реакций, так и роста бактерий. В статье проведено исследование влияния $\mathrm{pH}$ и температуры на окисление сульфата железа природными штаммами Acidithiobacillus ferrooxidans и Acidithiobacillus ferrivorans. Эксперименты на биоокисление проводились в колбах на качалке при температурах $28^{\circ} \mathrm{C}$ и $8{ }^{\circ} \mathrm{C}$ и при начальном $\mathrm{pH} 1,6$ в течение 5 дней. В результате мезофильные окислители железа были способны расти на двухвалентном железе при концентрациях 4,5 г/л при низкой температуре. Однако скорость мезофильного биоокисления двухвалентного железа была выше, чем при психрофильном биоокислении. Таким образом, во время эксперимента штаммы Acidithiobacillus ferrivorans 535 показали высокую активность в окислении при низкой температуре, чем другие. Это означает, что даже при очень низких температурах микроорганизмы играют важную роль в окислении и выщелачивании сульфидных руд.
\end{abstract}

Ключевые слова: биовыщелачивание, Acidithiobacillus ferrooxidans, Acidithiobacillus ferrivorans, биоокисление, двухвалентное железо, психрофильное биоокисление, мезофильное биоокисление, низкая температура, окисление железа, сульфидные руды. 